\title{
Targeted disruption of the aromatase $P 450$ gene (Cyp19) in mice and their ovarian and uterine responses to $17 \beta$-oestradiol
}

\author{
K Toda, K Takeda ${ }^{3}$, T Okada ${ }^{1}$, S Akira ${ }^{3}$, T Saibara ${ }^{2}$, T Kaname ${ }^{4}$, \\ K Yamamura ${ }^{4}$, S Onishi ${ }^{2}$ and $Y$ Shizuta \\ Department of Medical Chemistry, Kochi Medical School, Nankoku, Kochi 783-8505, Japan \\ ${ }^{1}$ Department of Anatomy and Cell Biology, Kochi Medical School, Nankoku, Kochi 783-8505, Japan \\ ${ }^{2}$ Department of Internal Medicine, Kochi Medical School, Nankoku, Kochi 783-8505, Japan \\ ${ }^{3}$ Department of Host Defense, Research Institute for Microbial Diseases, Osaka University, Suita, Osaka 565-0871, Japan \\ ${ }^{4}$ Department of Developmental Genetics, Institute of Molecular Embryology and Genetics, Kumamoto University School of Medicine, Kuhonji, \\ Kumamoto 862-0976, Japan \\ (Requests for offprints should be addressed to K Toda; Email: todak@kochi-ms.ac.jp)
}

\begin{abstract}
Aromatase P450 (CYP19) is an enzyme catalysing the conversion of androgens into oestrogens. We generated mice lacking aromatase activity (ArKO) by targeted disruption of Cyp19 and report the characteristic features of the ArKO ovaries and uteri as revealed by histological and biochemical analyses.

ArKO females were totally infertile but there were as many developing follicles in their ovaries at 8 weeks of age as in wild-type ovaries. Nevertheless, no typical corpus luteum was observed in the ArKO ovaries. Electron microscopy revealed the presence of well-developed smooth endoplasmic reticulum, few lipid droplets and mitochondria with less organized tubular structures in the ArKO luteinized interstitial cells. These ultrastructural features were different from those of the wild-type interstitial cells, where there are many lipid droplets and mitochondria with well-developed tubular structures, characteristic of steroid-producing cells.

When ArKO mice were supplemented with $17 \beta$ oestradiol $\left(E_{2} ; 15 \mu \mathrm{g} /\right.$ mouse $)$ every fourth day from 4 weeks of age for 1 month, increased numbers of follicles were observed in the ovaries as compared with those of untreated ArKO mice, although no typical corpus luteum
\end{abstract}

was detectable. Ultrastructural analysis revealed the disappearance of the accumulated smooth endoplasmic reticulum in the luteinized interstitial cells after $\mathrm{E}_{2}$ supplementation. Transcripts of pro-apoptotic genes such as p53 and Bax genes were markedly elevated in the ArKO ovaries as compared with those of wild-type mice. Although $\mathrm{E}_{2}$ supplementation did not cause suppression of the elevated expression of p53 and Bax mRNAs, it caused marked enhancement of expression levels of lactoferrin and progesterone receptor mRNAs in the uteri as well as increases in uterine wet weight. At 8 months of age, ArKO mice developed haemorrhages in the ovaries, in which follicles were nearly depleted, while age-matched wild-type females still had many ovarian follicles. Furthermore, macrophage-like cells were occasionally observed in the ArKO ovarian follicles.

These results suggested that targeted disruption of Cyp19 caused anovulation and precocious depletion of ovarian follicles. Additionally, analysis of mice supplemented with $\mathrm{E}_{2}$ demonstrated that $\mathrm{E}_{2}$ apparently supports development of ovarian follicles, although it did not restore the defect in ovulation.

Journal of Endocrinology (2001) 170, 99-111

\section{Introduction}

Less than $0 \cdot 1 \%$ of the follicles present at birth mature and ovulate, whereas the rest undergo atretic degeneration (Hsueh et al. 1994, McGee \& Hsueh 2000). Because atresia is a prominent feature of ovarian follicular development in mammals throughout female reproductive life (Hirshfield 1991), the hormonal mechanisms controlling cell death have been extensively studied (Hsueh et al. 1994, Richards 1994). These studies have demonstrated the important role of growth factors as survival factors to suppress ovarian atresia. These include epidermal growth factor/transforming growth factor $\alpha$, insulin-like growth factor-I, basic fibroblast growth factor and gonadotrophins (Braw \& Tsafriri 1980, Tilly et al. 1992, Billig et al. 1994, Chun et al. 1994, 1996, Eisenhauer et al. 1995). Additionally, the ovarian steroid, oestrogen, has been shown to be an important factor in the events leading to ovulation, because oestrogen regulates ovarian follicular development by stimulating granulosa cell proliferation, increasing the formation of gap junctions between granulosa cells, and enhancing follicle-stimulating hormone-stimulated gene 
expression in granulosa cells, in addition to its role in the hypothalamus and pituitary gland (Hsueh et al. 1994, Richards 1994). The importance of oestrogen in ovarian functions is further suggested by studies using hypophysectomized rats, demonstrating that treatment with oestrogen prevents decreases in ovarian weight and ovarian apoptotic DNA fragmentation induced by hypophysectomy (Billig et al. 1993).

The main site of oestrogen synthesis, which is catalysed by an enzyme called aromatase P450 (CYP19), is in ovarian granulosa cells at reproductive ages (Yamada et al. 1993, Shoham \& Schachter 1996). Therefore, the majority of studies have employed surgical manipulations or pharmacological administration of oestrogen agonists or antagonists to study the roles of oestrogens in the ovary. Although this approach is valid, it remains uncertain whether oestrogen synthesis is blocked definitively or the agonists/antagonists compete completely with the endogenous ligands under those experimental conditions. Thus, genetically engineered mice, which are devoid of oestrogen biosynthesis or the signalling pathways of oestrogens, provide another experimental approach to characterize and clarify the intraovarian processes dependent upon oestrogens in intact animals. Recently, mice lacking oestrogen receptor $\alpha$ (ER $\alpha$ : called $\alpha E R K O)$ (Lubahn et al. 1993, Eddy et al. 1996, Hess et al. 1997, Couse \& Korach 1999, Schomberg et al. 1999, Dupont et al. 2000), ER $\beta$ ( $\beta E R K O)$ (Krege et al. 1998, Dupont et al. 2000, Weihua et al. 2000) or both the receptors, ER $\alpha$ and $\beta$ ( $\alpha \beta E R K O)$ (Couse et al. 1999, Dupont et al. 2000), have been generated. Studies on these mice demonstrated the significant contributions of the oestrogen-regulated pathways in female ovarian functions as well as roles in males (Eddy et al. 1996, Hess et al. 1997). aERKO females are infertile and the ovaries appear hyperaemic and are blocked in follicular development at the preovulatory stage. The $\beta E R K O$ females are fertile but the ovaries show a partial arrest of follicular development and less frequent follicular maturation as compared with wild-type animals. We here report the generation of aromatase $\mathrm{P} 450$ knockout mice by targeted disruption of Cyp19 (ArKO mice), and morphological and biochemical characterization of the ovaries and uteri. The phenotype of ArKO female mice, such as infertility and anovulation, is consistent with that of ArKO mice generated independently using different targeting strategies (Fisher et al. 1998, Honda et al. 1998, Britt et al. 2000). In the present study, we further report the effects of supplementation with $17 \beta$-oestradiol $\left(\mathrm{E}_{2}\right)$ on the reproductive organs of ArKO females.

\section{Materials and Methods}

\section{Materials}

eLONGase enzyme mix and Moloney murine leukaemia virus reverse transcriptase were purchased from
Gibco-BRL (Rockville, MD, USA). Androst-4-ene3,17-dione, $[1 \beta-3 \mathrm{H}(\mathrm{N})]-(24 \mathrm{Ci} / \mathrm{mmol})$ was purchased from New England Nuclear Life Science Products, Inc. (Boston, MA, USA). Human chorionic gonadotrophin (hCG), $\mathrm{E}_{2}$ and 4-androsten-4-ol-3,17-dione were obtained from Sigma-Aldrich (Tokyo, Japan). Pregnant mare serum gonadotrophin (PMSG) was obtained from Teikoku hormone MFG Co. Ltd (Tokyo, Japan). A standard rodent chow (NMF) was obtained from Oriental Yeast (Tokyo, Japan). Oestradiol and total testosterone kits for radioimmunoassay analysis were obtained from Japan DPC Corp. (Tokyo, Japan). Spurr's epoxy resin was purchased from Polysciences, Inc. (Warrington, PA, USA). All other chemicals were of analytical grade and obtained commercially.

\section{Animals}

Animal care and experiments were carried out in accordance with institutional animal regulations. All animals were maintained on a $12 \mathrm{~h}$ light: $12 \mathrm{~h}$ darkness cycle at $22-25{ }^{\circ} \mathrm{C}$ and fed with standard rodent chow and water ad libitum. For comparison of phenotypes, wild-type and knockout mice from the same litters were used. To induce ovulation, female mice at 5 weeks of age were injected with PMSG (i.p., $5 \mathrm{IU} /$ mouse) and then given hCG (i.p., $5 \mathrm{IU} /$ mouse) $48 \mathrm{~h}$ later. Ovulation was determined by surgical extraction of oocyte/cumulus masses from oviducts $18 \mathrm{~h}$ after the second injection (Hogan et al. 1994). To examine the effects of $\mathrm{E}_{2}$, ArKO females $(n=7)$ at 4 weeks of age were given s.c. injections of $\mathrm{E}_{2}$ dissolved in sesame oil $(15 \mu \mathrm{g} / 25 \mu \mathrm{l}$ per mouse per injection) every fourth day for 4 weeks. A group of ArKO mice was given s.c. injections of sesame oil alone. At 8 weeks of age, the ovaries and uteri were removed from the animals and used for analyses.

\section{Structural analysis of Cyp19}

DNA fragments containing exons of Cyp19 were amplified by polymerase chain reaction (PCR) using $0 \cdot 1 \mu \mathrm{g}$ total genomic DNA of E14-1 embryonic stem (ES) cells with eLONGase enzyme mix according to the manufacturer's instructions. Primers for amplifications were designed according to nucleotide sequence of murine CYP19 cDNA (Terashima et al. 1991). (The sequences and locations of the primers used in this study are available on request.) Amplified fragments were confirmed by hybridization with radiolabelled primers located within the fragments and by nucleotide sequence analysis.

\section{Generation of ArKO mice}

The targeting vector was designed based on the exonintron organization of Cyp19, in which an 87 bp fragment located within exon 9, corresponding to nucleotide position +1124 to +1210 relative to the translational start 
site in the mature mRNA (corresponding amino acid residue number 375-402), was replaced with the neomycin-resistance gene derived from pMC1-neo (Thomas \& Capecchi 1987). The herpes-simplex virus thymidine kinase gene was inserted at the $5^{\prime}$ end of an $8.5 \mathrm{~kb}$ fragment, containing exons $5,6,7,8$, and the $5^{\prime}$ part of exon 9 (Fig. 1A). The linearized target vector was electroporated into the ES cells (Takeda et al. 1996). Two ES cell clones out of 493 independent colonies, formed in the presence of G418 and gancyclovir, were confirmed as correctly targeted. The ES cells were microinjected into $\mathrm{C} 57 \mathrm{BL} / 6 \mathrm{~J}$ blastocysts to generate chimeric mice. Chimeric male mice were then mated with C57BL/6J female mice to generate mice heterozygous for the mutation, which were then intercrossed to generate mice homozygous for the Cyp19 mutation (ArKO). ArKO mice derived from the two ES cell clones showed similar phenotypes. When the offspring reached 3 weeks of age, their genotypes were determined by PCR amplification using tail genomic DNAs.

\section{Preparation and analysis of RNA}

Total RNAs were prepared from ovaries or uteri of wild-type mice, ArKO mice and $\mathrm{E}_{2}$-treated ArKO mice at 8 weeks of age according to the method of Mirkes (1985). The uterine tissue samples from five animals were combined and used for RNA preparation, as the tissue of the ArKO mouse is diminished in size. For the preparation of ovarian RNA, we used five animals for both genotypes. One microgram of each RNA was used for reverse transcription with $10 \mathrm{pmol}$ of an oligo dT primer in a final volume of $20 \mu \mathrm{l}$ using Moloney murine leukaemia virus reverse transcriptase. Subsequent PCR analysis was carried out with $1 \mu \mathrm{l}$ of the cDNA (equivalent to $0.05 \mu \mathrm{g}$ total RNA) with a set of primers to amplify fragments containing nucleotide sequences of exons 4 and 6 or exons 8 and 9 of Cyp19 and exons 6 and 7 of Cyp17. The products were analysed by electrophoresis on $5 \%$ polyacrylamide gels. The amplified fragments were verified by nucleotide sequence analysis. Twenty micrograms of the total RNA was used for Northern blot analysis according to the method described (Sambrook et al. 1989). A cDNA probe for lactoferrin was a generous gift from Dr C T Teng (National Institute of Environmental Heath Science, Research Triangle Park, NC, USA). cDNA probes for p53, Bax, scavenger receptor class B type I (SR-BI) and progesterone receptor were prepared by PCR amplification with a set of primers based on the nucleotide sequences (details available on request). The cDNAs obtained were verified by the nucleotide sequence analysis.

\section{Construction of the expression vectors of murine Cyp19 and their expression in vitro}

Full-length, truncated and deleted forms of Cyp 19 cDNA were prepared by PCR amplification using pES-M1 as template DNA (Terashima et al. 1991). The full-length, truncated and deleted forms of the cDNA encompass the nucleotide sequence from -4 to +1497 , from -4 to +1123 and from -4 to +1497 without sequences between +1124 and +1210 , relative to the translational start site, respectively. The fragments were inserted into the EcoRV site of an expression vector, pcDNA1·1/Amp (Invitrogen, Groningen, The Netherlands). Each construct together with a $\beta$-galactosidase expression plasmid, pCH110, was transfected by the calcium-phosphate method into human endometrial carcinoma cells (HEC-59) (Tada et al. 1993), which were cultured in a Dulbecco's modified Eagle's medium (pH 7•4) (DMEM) supplemented with $10 \%$ fetal bovine serum in a $35 \mathrm{~mm}$ dish. After incubation for 3 days, aromatase activity was measured.

\section{Aromatase assay}

A tritiated water-release assay was employed to measure aromatase activity (Lephart \& Simpson 1991). After the culture medium was changed to $1 \mathrm{ml}$ DMEM without serum, the enzyme reaction was initiated by the addition of $300 \mathrm{pmol}$ androst-4-ene-3,17-dione, $[1 \beta-3 \mathrm{H}(\mathrm{N})]-$ with or without $10 \mu \mathrm{M} 4$-androsten-4-ol-3,17-dione, an aromatase inhibitor (Brodie et al. 1977). The reaction was carried out at $37^{\circ} \mathrm{C}$ for $4 \mathrm{~h}$. When the activity in the ovaries was measured, two females at 10-12 weeks of age were used for each measurement. Whole ovarian dispersates in $1 \mathrm{ml}$ DMEM in a $35 \mathrm{~mm}$ dish were prepared mechanically using fine forceps and incubated with the tritiated substrate as above. Aromatase activity was expressed as fmol $\left[{ }^{3} \mathrm{H}\right]$ water released/dish per $\beta$-galactosidase activity per $h$ (means \pm s.E.M. of data derived from four independent experiments) for the in vitro expressed enzyme and fmol $\left[{ }^{3} \mathrm{H}\right]$ water released per mg wet weight per $\mathrm{h}$ (means \pm s.E.M. of data derived from seven independent experiments) for the ovarian activity.

\section{Analysis of serum steroids}

Blood was collected by cardiac puncture from anaesthetized animals. Serum samples from three to four mice of each genotype at 16-20 weeks of age were mixed. Of the serum mixture, $0.5 \mathrm{ml}$ and $0.3 \mathrm{ml}$ were used for the determination of $E_{2}$ and testosterone concentrations respectively, using radioimmunoassay kits according to the manufacturer's instructions. The measurements were done at least three times using serum samples collected from different groups of animals.

\section{Histological examination}

Five ArKO and wild-type females at 8 weeks of age or 8 months of age were used for histological study. ArKO mice treated with $E_{2}$ or vehicle alone were also subjected 
to histology. Ovaries and uteri removed from mice were fixed in a solution of $10 \%$ buffered formalin for $24 \mathrm{~h}$, dehydrated and embedded in paraffin. Sections were cut $3 \mu \mathrm{m}$ thick and stained with haematoxylin-eosin. For electron microscopy, the tissues were cut into small pieces, immersed in a fixative containing $2 \%$ paraformaldehyde and $2 \%$ glutaraldehyde in $0.1 \mathrm{M}$ cacodylate buffer $(\mathrm{pH}$ $7 \cdot 2$ ) for $1 \mathrm{~h}$ at $4{ }^{\circ} \mathrm{C}$ followed by postfixation in $1 \%$ osmic acid in $0 \cdot 1 \mathrm{M}$ cacodylate buffer $(\mathrm{pH} 7 \cdot 2)$ for $1 \mathrm{~h}$ at $4{ }^{\circ} \mathrm{C}$. After fixation, the tissues were rinsed, dehydrated in graded ethyl alcohol and embedded in a Spurr's epoxy resin. Ultra-thin sections were doubly contrasted with uranyl acetic acid and lead citric acid, and observed with a Hitachi $\mathrm{H}-700 \mathrm{H}$ electron microscope.

\section{Statistical analysis}

Data were analysed by Wilcoxon rank-sum test, Wilcox signed rank test or chi-square test. The difference was regarded to be significant when $P<0 \cdot 05$.

\section{Results}

\section{Generation of ArKO mice}

Figure 1A shows the exon-intron organization of Cyp19. According to the gene structure, we constructed a targeting vector in which an $87 \mathrm{bp}$ protein coding sequence in exon 9 was replaced with the neomycin-resistance gene. Southern blot analysis demonstrated that Probe A located in intron 9 hybridized with $4.8 \mathrm{~kb}$ and $2.7 \mathrm{~kb}$ BamHI fragments derived from the wild-type and the mutated alleles respectively (Fig. 1B). Furthermore, PCR amplification of the wild-type genomic DNA using a set of primers respectively located in exons 8 and 9 yielded a $5.5 \mathrm{~kb}$ fragment, whereas the amplification of genomic DNA from mice heterozygous for the mutation generated a $6.5 \mathrm{~kb}$ fragment in addition to the $5.5 \mathrm{~kb}$ fragment. Both fragments positively hybridized with Probe A, while only the $6.5 \mathrm{~kb}$ fragment was detected with the probe, Probe $\mathrm{N}$, located in the neomycin-resistance gene (Fig. 1C). Thus, the conditions of the PCR amplification allowed us to determine the genotype of offspring (Fig. 1D).

\section{Expression of aromatase P450 in the ovaries}

Expression of Cyp19 was analysed with RT-PCR using RNAs prepared from wild-type and ArKO ovaries. As shown in Fig. 2A, transcripts encompassing nucleotide sequence of exon 4 to exon 6 of Cyp 19 were detected in the cDNAs of the wild-type and ArKO ovaries, but those containing the sequence from exon 8 to exon 9 were detected only in the cDNAs of the wild-type ovaries. As a control amplification, comparable amounts of transcripts of Cyp 17 were detected in the ovaries of both genotypes.
Thus, these results established that transcripts with a full-length sequence were absent in ArKO mice. In order to ensure that the disruption of the gene resulted in a loss of the enzyme activity, we constructed expression vectors containing nucleotide sequences coding for full-length, truncated and deleted forms of CYP19 and measured the aromatase activity of the products expressed in cultured cells using the tritiated-water releasing method. As shown in Fig. 2B, the construct containing the full-length sequence expresses the functionally active enzyme, whereas neither the truncated nor deleted sequence in the expression vector generated products with aromatase activity. We measured the activity in the ovaries as shown in Fig. 2C. The aromatase activity in the ovaries of wild-type females was $16.1 \pm 5.0 \mathrm{fmol} / \mathrm{mg}$ wet weight per h, whereas it was greatly reduced in the presence of aromatase inhibitor $(1.42 \pm 0.74 \mathrm{fmol} / \mathrm{mg}$ wet weight per h). In the ArKO ovaries, we detected only negligible levels of the activity $(1.07 \pm 0.24 \mathrm{fmol} / \mathrm{mg}$ wet weight per h).

\section{Serum steroid levels}

The concentrations of steroids in serum are presented in Table 1. The concentrations of $E_{2}$ and testosterone in the wild-type females were $23.7 \mathrm{pg} / \mathrm{ml}$ and $132 \mathrm{pg} / \mathrm{ml}$ respectively. The concentration of testosterone in the wild-type male mice was $2630 \mathrm{pg} / \mathrm{ml}$. The levels of testosterone were markedly elevated in the ArKO mice, especially in the ArKO females, where they were approximately tenfold higher than in the wild-type females $(P<0 \cdot 0001)$. As expected, the levels of $\mathrm{E}_{2}$ in the ArKO mice were below the limit of detection in both females and males $(n=4$, detection limit $>10 \mathrm{pg} / \mathrm{ml})$.

\section{Fertility of ArKO females}

We observed that mice homozygous for the mutation were born with an expected ratio of the Mendelian frequency when the heterozygous mice were crossed. Continuous test mating revealed that ArKO females were totally infertile (tested by ten mates), while wild-type and heterozygous females were productive with similar frequencies and average litter sizes.

\section{Morphological and histological analysis of the female reproductive organs of ArKO mice}

Gross morphology of the reproductive organs at 8 weeks of age is shown in Fig. 3A and B. The uterine size of the mutant animal was markedly reduced (Fig. 3B) as compared with that of wild-type females (Fig. 3A). The wet weights of wild-type and ArKO uteri were $97.8 \pm 53.5 \mathrm{mg}$ and $14.5 \pm 1.98 \mathrm{mg}$ respectively (Fig. 4A). However, gross alteration in morphology of the organ was not apparent at this age. Histology of the ArKO ovaries demonstrated the presence of follicles at various 


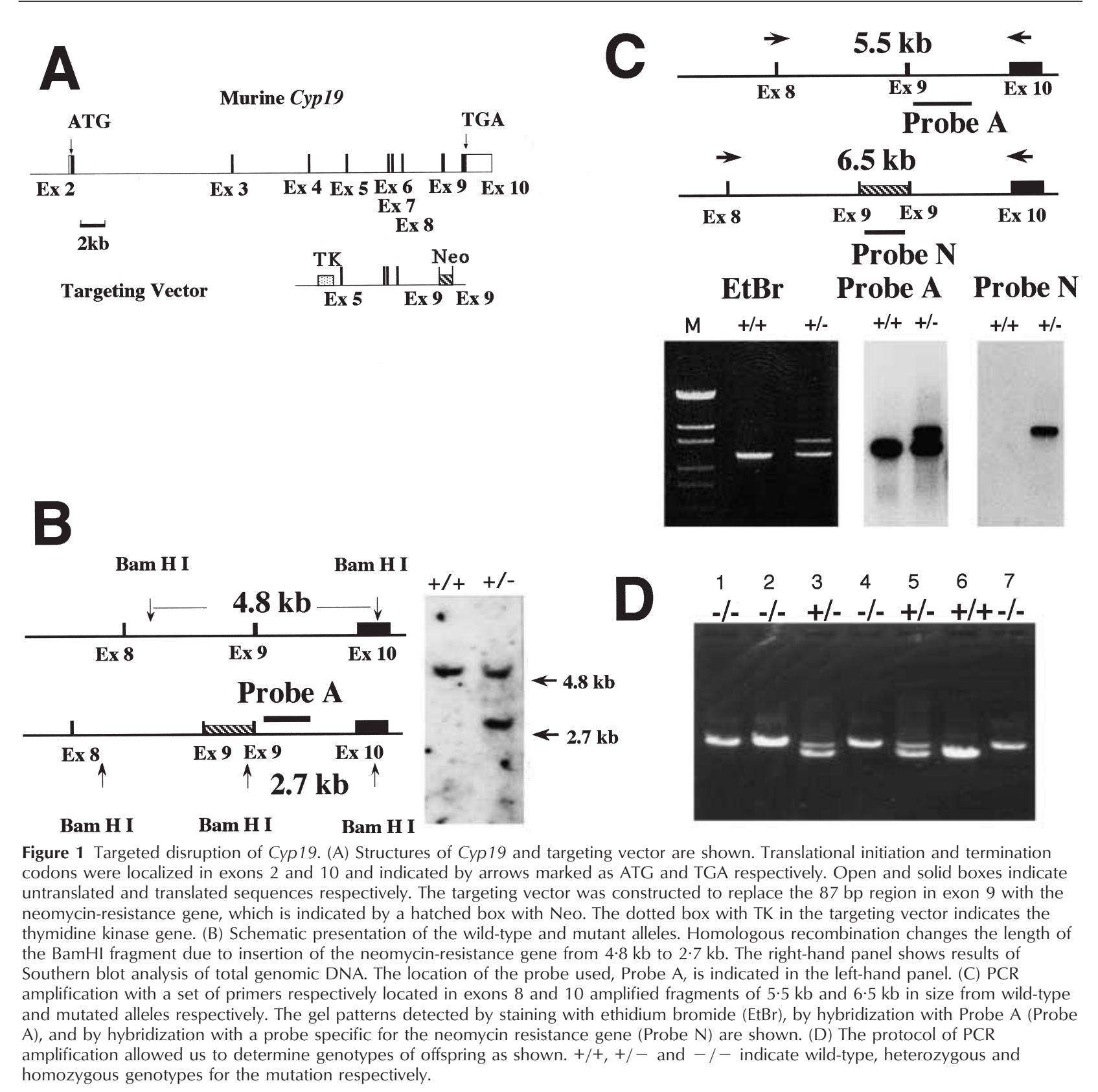

maturational stages including primary to large antral follicles (Fig. 3F). Nevertheless, we observed no corpus luteum in the ArKO ovaries, indicating anovulation. The defect in ovulation of ArKO females was further examined by an experiment to induce superovulation using mice at 5 weeks of age. Treatment with PMSG followed by injection of hCG induced ovulation in wild-type females, but not in ArKO females (data not shown). In accordance with anovulation, we observed fewer numbers of luteinized interstitial cells in the ArKO ovaries (Fig. 3G), which were markedly different from the wild-type ovaries, where corpora lutea were present (Fig. 3D) and the interstitial cells filled the intraovarian space (Fig. 3E). Histology of the ArKO uterus demonstrated a decrease in endometrial and myometrial thickness (Fig. 4B).

Ultramicroscopy revealed numerous lipid droplets and spherical mitochondria with tubular cristae and the high electron-dense matrix in the wild-type luteinized interstitial cells (Fig. 5A and B). In addition, little smooth endoplasmic reticulum was observed. In contrast, smooth endoplasmic reticulum that consisted of closely packed, branching and anastomosing tubules with similar 

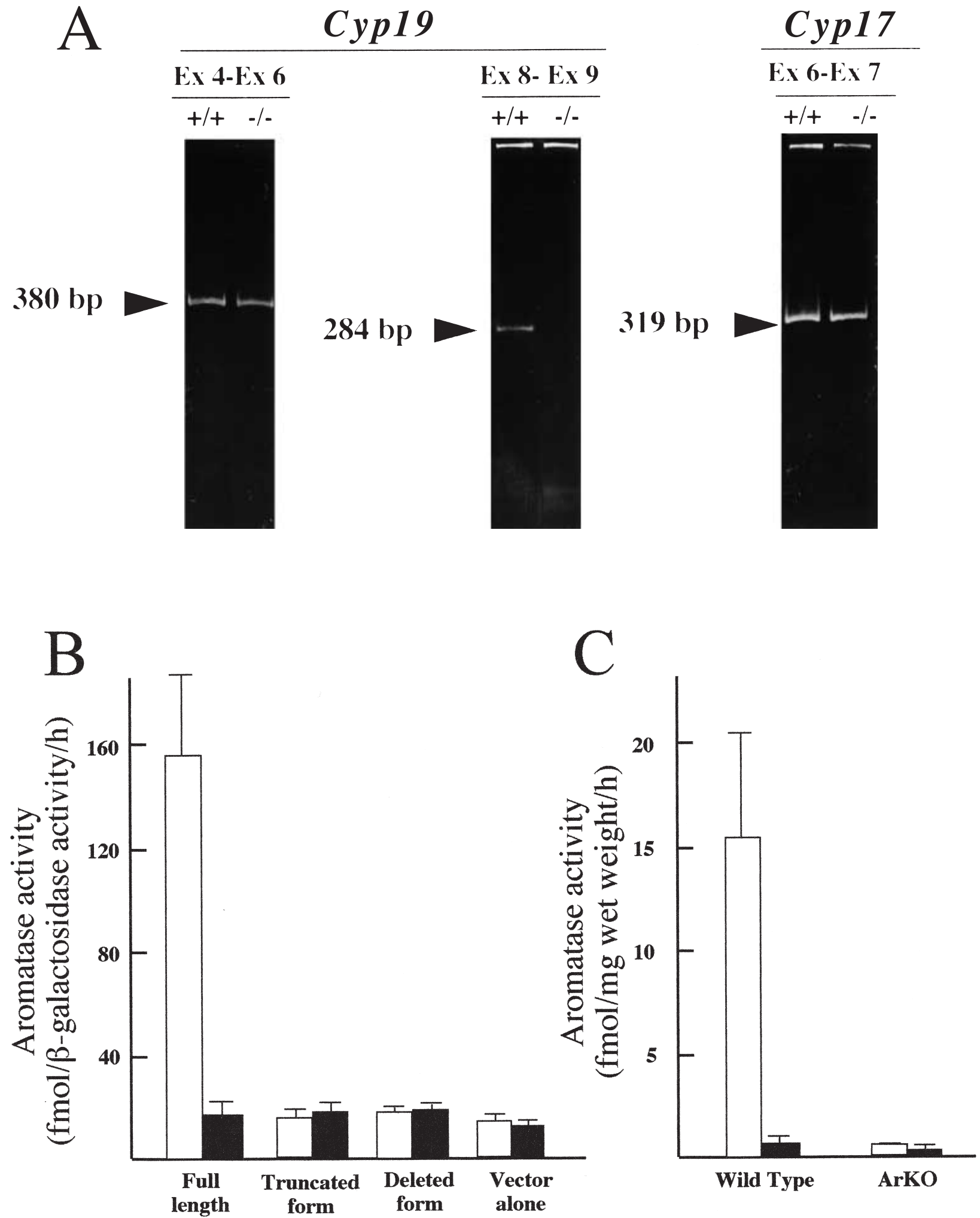
Table 1 Concentrations of $\mathrm{E}_{2}$ and testosterone in serum. Four pools of serum from three to four mice at 16-20 weeks of age were used to determine their means ( \pm S.E.M.). The limit for detection of $E_{2}$ was $10 \mathrm{pg} / \mathrm{ml}$ under the present experimental conditions

\begin{tabular}{|c|c|c|c|c|}
\hline \multicolumn{3}{|c|}{$\underline{\mathbf{E}_{\mathbf{2}}(\mathrm{pg} / \mathrm{ml})}$} & \multicolumn{2}{|c|}{ Testosterone (pg/ml) } \\
\hline & $+/+$ & $-1-$ & $+/+$ & $-1-$ \\
\hline Female & $23 \cdot 7 \pm 2 \cdot 9$ & $<10$ & $132 \pm 38 \cdot 5$ & $1381 \pm 498$ \\
\hline Male & $<10$ & $<10$ & $2630 \pm 718$ & $4996 \pm 1226$ \\
\hline
\end{tabular}

diameters occupied most of the cytoplasm of the ArKO luteinized interstitial cells (Fig. 5C and D). Furthermore, lipid droplets and rough endoplasmic reticula were rarely observed in the ArKO cells.

The gross anatomy of the reproductive organs of ArKO females at 8 months of age is presented in Fig. 3C. As in young animals, the uterine size was diminished. Furthermore, haemorrhagic formation in the ovaries was observed in the aged ArKO mice. Histological examination of the ArKO ovaries showed depletion of the follicles, formation of large haemorrhages (Fig. 3J) and the sporadic presence of macrophage-like cells in the follicular antrum (Fig. 3K). In addition, we observed mast cells in ArKO ovaries much more frequently than in the wild-type ovaries (data not shown).

\section{Alternations in gene expression in the ovaries and uteri of ArKO mice}

Because ArKO females are defective in ovulation, the ovarian follicles undergo atretic degeneration. As apoptosis seems to be one of the underlying mechanism for the process, we examined expression levels of the p53 and Bax genes in ArKO ovaries by Northern blot analysis. As shown in Fig. 6A, the levels of the p53 and Bax genes in ArKO ovaries were elevated as compared with those in the wild-type ovaries $(3 \cdot 3 \pm 0 \cdot 12$-fold for $\mathrm{p} 53$ and $1 \cdot 8 \pm 0 \cdot 2$-fold for Bax over the wild-type levels respectively). In contrast, comparable levels of SR-BI expression were observed in the wild-type and ArKO ovaries
$(0 \cdot 89 \pm 0 \cdot 2$-fold over the wild-type levels). When we examined uterine expression levels of the lactoferrin and progesterone receptor genes, which are well documented to be transcribed under the regulation of oestrogen, the levels in ArKO mice were found to be much lower than those in wild-type mice (Fig. 6B). These results further support a loss of the function of Cyp19 in ArKO mice.

\section{Effects of $E_{2}$ supplementation on ovaries and uteri of $\mathrm{ArKO}$ mice}

When ArKO females at 4 weeks of age were supplemented with $E_{2}$ every fourth day for 4 weeks, greater numbers of ovarian follicles were evident in the treated ovaries compared with those of age-matched untreated ArKO mice (Fig. 3H) Furthermore, we observed many luteinized interstitial cells in the intraovarian space (Fig. 3I). Nevertheless, we did not detect a typical corpus luteum in the $\mathrm{E}_{2}$-treated ovaries. These results indicate that $\mathrm{E}_{2}$ might be able to support development of ovarian follicles, but is not sufficient to promote ovulation of the follicles. Electron microscopy demonstrated that the $\mathrm{E}_{2}$ supplementation reverses the unusual accumulation of smooth endoplasmic reticulum in the luteinized interstitial cells of ArKO ovaries (Fig. 5E and F). Furthermore, we observed lipid droplets in the cytosol of the interstitial cells and mitochondria with structures showing characteristics of steroid-producing cells. Although $\mathrm{E}_{2}$ supplementation supported development of ovarian follicles, the treatment did not affect the expression levels of p53 (3.5 $\pm 0 \cdot 2$-fold) and $\operatorname{Bax}(1 \cdot 5 \pm 0 \cdot 1$-fold $)$ mRNAs at all in the ArKO ovaries as analysed by Northern blot analysis (Fig. 6A).

When ArKO mice received $\mathrm{E}_{2}$, the uterine size of ArKO mice, which was approximately $15 \%$ of the size of the wild-type uteri, was markedly increased $(89 \cdot 2 \pm 19 \cdot 4 \mathrm{mg})$, reaching levels of wild-type females $(97 \cdot 8 \pm 53.5 \mathrm{mg})$ (Fig. 4A). Histological analysis confirmed the proliferation of cells in the endometrium as well as in the myometrium (Fig. 4B). Northern blot analysis also revealed marked enhancement of the lactoferrin and progesterone receptor gene expression, 2.7-fold and $1 \cdot 3$-fold over the levels of the wild-type mice respectively

\footnotetext{
Figure 2 Functional disruption of Cyp19. (A) Expression of Cyp19 in the ovaries. Total RNAs prepared from the wild-type (+/+) or ArKO $(-/-)$ ovaries were reverse transcribed. A portion of the cDNAs was used for PCR amplification of fragments encompassing exon (Ex) 4 to $6(380 \mathrm{bp})$ or exon 8 to 9 (284 bp) of Cyp 19 , and exon 6 to 7 (319 bp) of Cyp 17. (B) Aromatase activity expressed in vitro. The activity was assayed by the tritiated water-releasing method. The cells were transfected with an expression vector containing a full-length form (full-length), a truncated form (truncated form) or a deleted form (deleted form) of the Cyp19 cDNA, or the expression vector alone (vector alone). After incubation for 3 days, androst-4-ene-3,17-dione, $[1 \beta-3 \mathrm{H}(\mathrm{N})]$ - was added and cells were incubated at $37^{\circ} \mathrm{C}$ for $4 \mathrm{~h}$ in the absence (open bars) or presence (solid bars) of the aromatase inhibitor, $10 \mu \mathrm{M} 4$-androsten-4-ol-3,17-dione, in serum-free DMEM. The radioactivity released from the substrate into the medium as a form of $\mathrm{H}_{2} \mathrm{O}$ was determined. The activity is expressed as fmol tritiated water released/ $\beta$-galactosidase activity/h. Each bar represents the mean \pm S.E.M. of four experiments. The endogenous tritiated water-releasing activity of the host cells is $18 \cdot 7 \pm 4 \cdot 2 \mathrm{fmol} / \mathrm{h}$ per dish and $20 \cdot 8 \pm 1 \cdot 1 \mathrm{fmol} / \mathrm{h}$ per dish in the absence and presence of $10 \mu \mathrm{M}$ 4-androsten-4-ol-3,17-dione respectively. (C) Aromatase activity in the wild-type and the ArKO ovaries. Whole ovarian dispersates from each genotype in serum-free DMEM were incubated with the radioactive substrate in the absence (open bars) or presence (solid bars) of $10 \mu \mathrm{M}$ 4-androsten-4-ol-3,17-dione to measure tritiated water-releasing activity. The activity was expressed as fmol tritiated water released/mg wet weight/h. Each bar represents the mean \pm S.E.M. of seven experiments.
} 


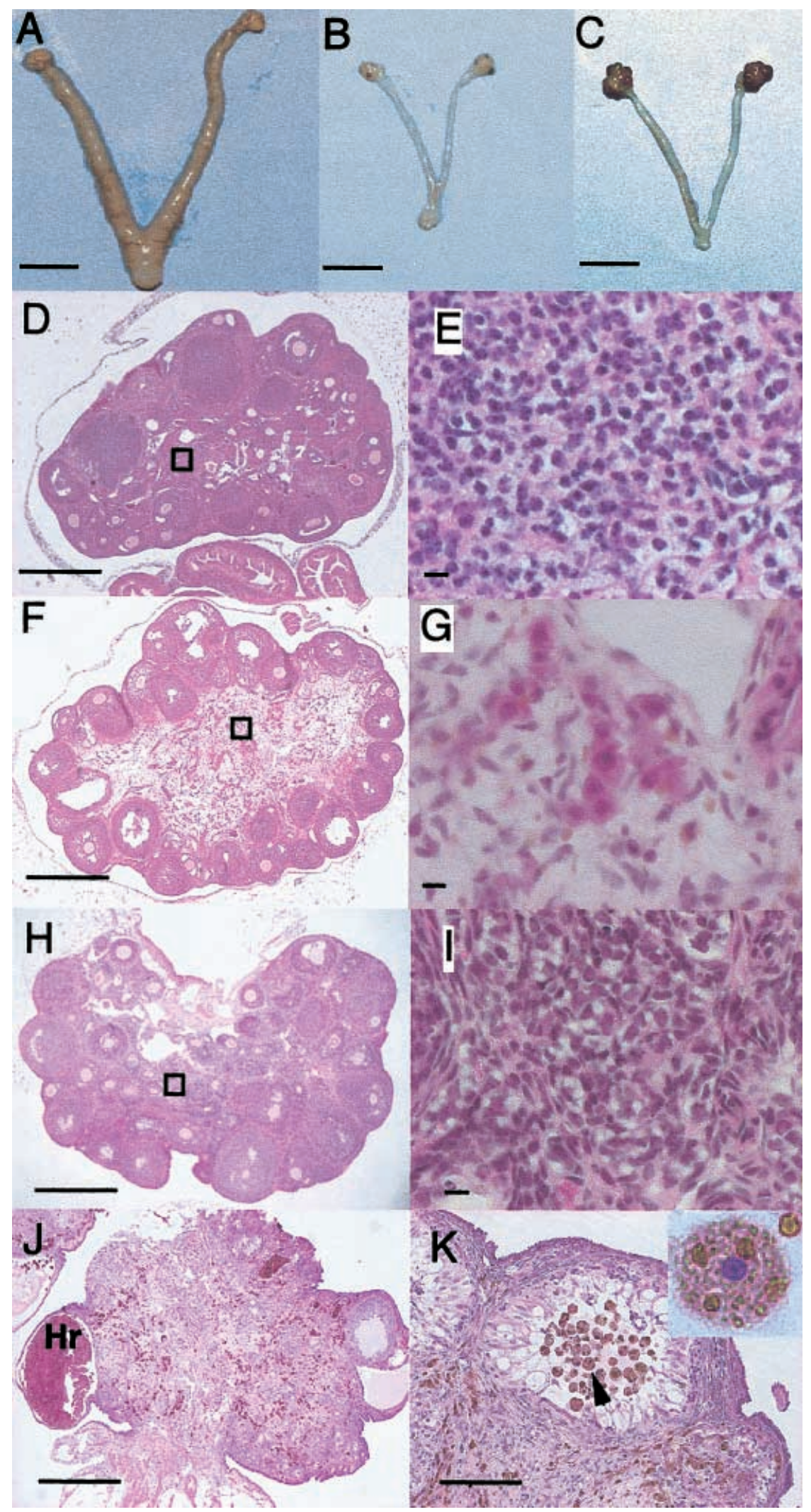



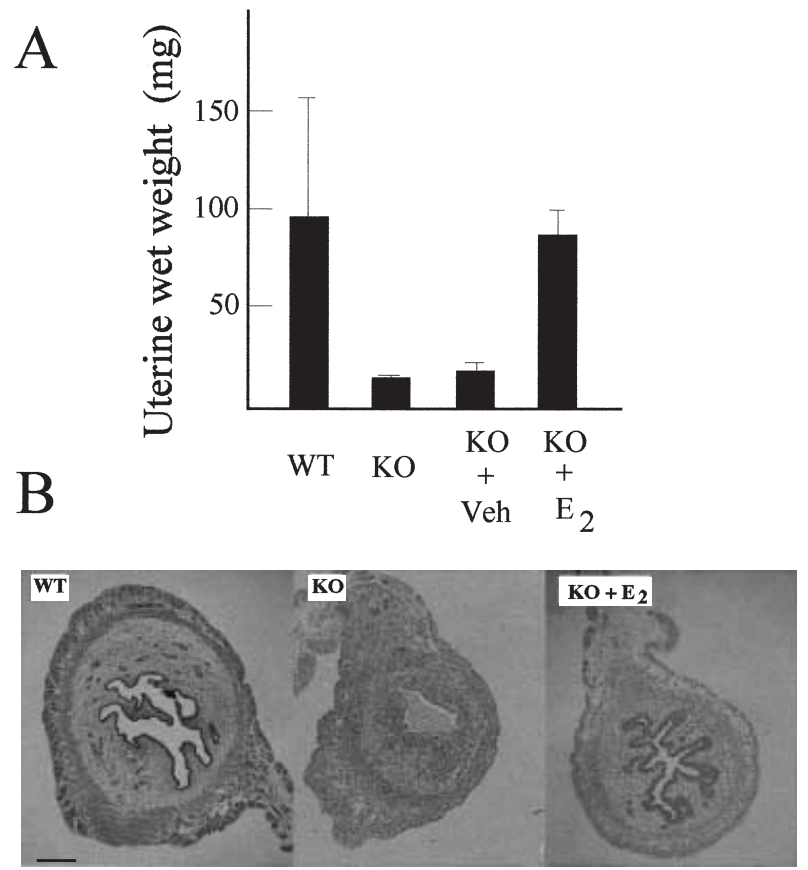

Figure 4 Uterine phenotype in ArKO mice. (A) Uterine wet weight and effects of $E_{2}$ supplementation. The uteri of wild-type mice $(\mathrm{WT})$, ArKO mice $(\mathrm{KO})$, ArKO mice that received vehicle alone $(\mathrm{KO}+\mathrm{Veh})$ and ArKO mice that received $\mathrm{E}_{2}(\mathrm{KO}+\mathrm{E} 2)$ at 8 weeks of age were measured. Wet weights of the wild-type uteri show large variations, which may result from the mice being at different stages of the oestrous cycle. (B) Histology of the uteri. The uteri of wild-type mice (WT) and ArKO mice (KO), and ArKO mice that received $E_{2}\left(K O+E_{2}\right)$ were used for histology. The wild-type female was at the metoestrus stage of the oestrous cycle. Increases in thickness in the endometrial and myometrial cell layers are evident in ArKO mice treated with $\mathrm{E}_{2}\left(\mathrm{KO}+\mathrm{E}_{2}\right)$. Furthermore, a number of glands are seen in the uterus of the treated ArKO mouse. Bar: $300 \mu \mathrm{m}$.

(Fig. 6B). These results indicated that the oestrogen signalling pathway is functional, at least, in the uteri of ArKO mice.

\section{Discussion}

In the present study, we generated aromatase knockout mice in order to assess the roles of oestrogen in the ovary. Targeted disruption of Cyp 19 was confirmed by RT-PCR analysis, which demonstrated the absence of full-length transcripts of Cyp19 in the ovaries and also in other tissue sites examined, including testes and brains (data not shown). Furthermore, the aromatase activity in the ovaries of ArKO mice was greatly reduced. The in vitro expression study provided evidence that deletion of the nucleotide sequence between +1124 and +1210 relative to the translational start site, which was the region to be replaced with the neomycin-resistance gene in the present knockout strategy, resulted in a complete loss of the aromatase activity. The replaced nucleotide sequence encodes one of the highly conserved regions of the CYP19 protein, which is referred to as the I-helix and believed to form the substrate-binding pocket proximal to the heme prosthetic group (Graham-Lorence et al. 1991). Therefore, the complete inactivation of enzyme activity by the replacement appears to be highly plausible. Nevertheless, we were unable to exclude completely the possibility that some other unidentified gene product with aromatase activity is present, as suggested by the study on the $\alpha \beta E R K O$ mice (Couse et al. 1999), because we observed very low tritiated water-releasing activity in the ArKO ovaries. However, the activity appears to be unable to generate sufficient quantities of oestrogens to exert physiological effects in the mice, because ArKO females are infertile and their uteri are markedly diminished in size. We also observed that hepatic expression of fatty acidmetabolizing enzymes was severely impaired in ArKO males (Nemoto et al. 2000).

The formation of haemorrhagic cysts on the surface of ovaries is one of the characteristic features of aged ArKO females. We occasionally observed macrophage-like cells in the follicular antrum of the ArKO ovaries, where they appear to act as phagocytes to remove superfluous cells. In contrast, invasion of macrophages into the follicular antrum of the wild-type ovaries was seldom observed under microscopic examinations. Thus, it was suggested that under specific physiological conditions such as absence of oestrogens (or excess of androgens), macrophages might invade into the follicular antrum, phagocytose and produce an empty space in the follicle, into which blood flows and accumulates, consequently leading to the formation of a haemorrhagic cystic follicle.

When ArKO mice were supplemented with $\mathrm{E}_{2}$ by subcutaneous injections, the wet weight of the uteri and the uterine expression of oestrogen-regulated genes, such as the lactoferrin and progesterone receptor genes, was markedly increased. However, neither anovulation nor the

Figure 3 Gross morphology and histology of female reproductive organs of wild-type and ArKO mice. (A-C) Gross anatomy of female reproductive organs of wild-type (A) and ArKO (B) mice at 8 weeks of age, and an ArKO mouse (C) at 8 months of age. Haematoxylineosin staining of the sections of ovaries of the wild-type ( $\mathrm{D}$ and $\mathrm{E}$ ), ArKO (F and $\mathrm{G}$ ) mice at 8 weeks of age, ovary of ArKO mouse treated with $E_{2}$ every fourth day for 1 month from 4 weeks of age $(\mathrm{H}$ and $\mathrm{I})$, and ovary of ArKO mouse at 8 months of age (J and K). The images shown at higher magnification ( $\mathrm{E}, \mathrm{G}$ and $\mathrm{I}$ ) are from the areas indicated by boxes in $\mathrm{D}, \mathrm{F}$ and $\mathrm{H}$ respectively. Hr in panel $\mathrm{J}$ indicates a haemorrhagic cyst. Note that one nucleus and many phagocytosed materials are observed in a macrophage-like cell at higher magnification, as shown in the insert in panel $\mathrm{K}$. The location of this cell is indicated by an arrow. Bars: $7 \mathrm{~mm}$ for $\mathrm{A}-\mathrm{C} ; 500 \mu \mathrm{m}$ for $\mathrm{D}, \mathrm{F}, \mathrm{H}$ and J; $125 \mu \mathrm{m}$ for $\mathrm{K} ; 10 \mu \mathrm{m}$ for $\mathrm{E}, \mathrm{G}$ and I. 


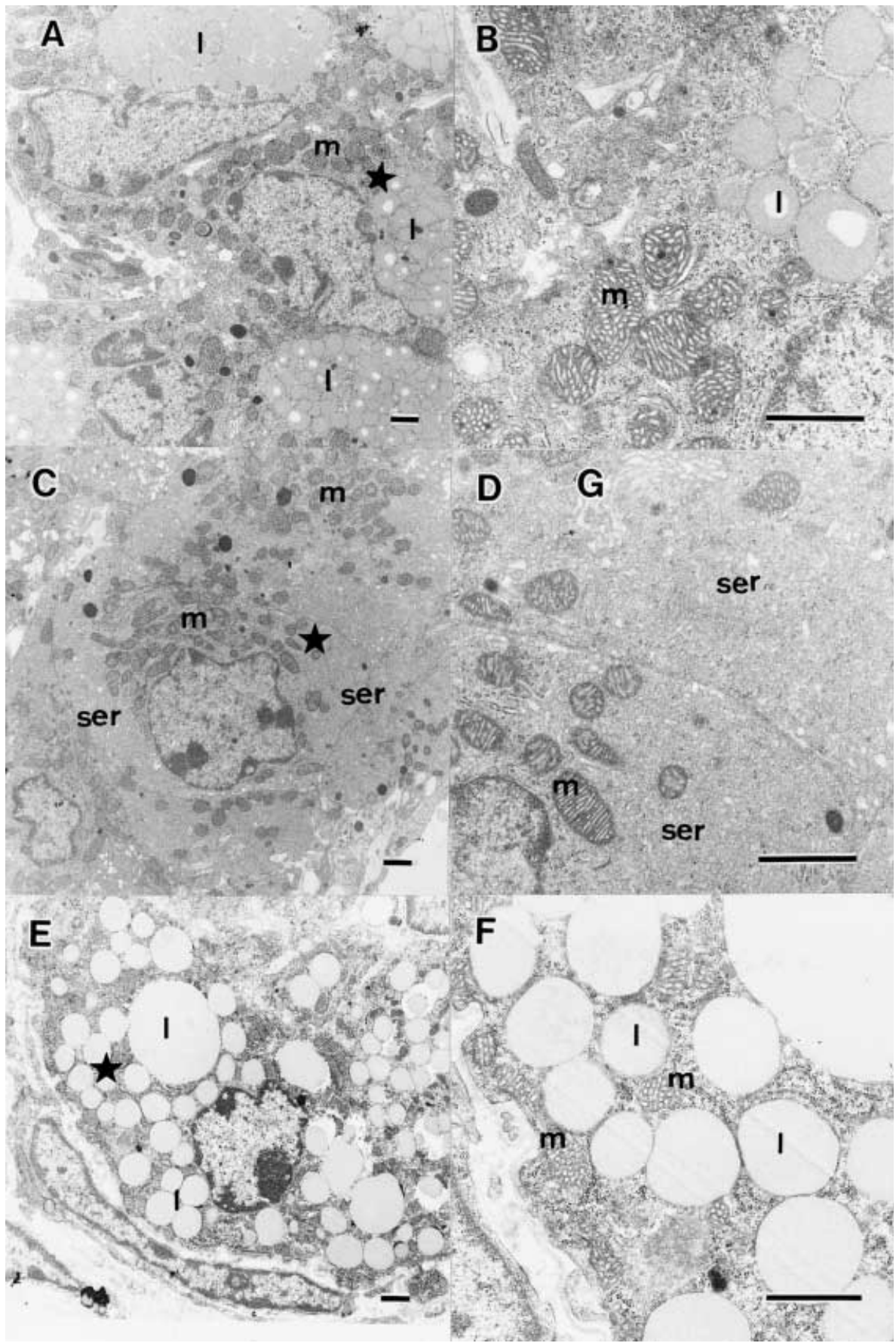

Figure 5 Ultrastructure of the luteinized interstitial cells. The ovarian luteinized interstitial cells of wild-type $(A$ and $B), \operatorname{ArKO}(C$ and $D)$ and $\operatorname{ArKO}$ mice treated with $E_{2}$ (E and $F$ ) were analysed by electron microscopy. Photographs of $\mathrm{B}, \mathrm{D}$ and $\mathrm{F}$ are higher magnification views of the areas marked by a star in A, C and E respectively. Many lipid droplets (I) and mitochondria ( $\mathrm{m}$ ) showing the characteristic structure of steroid-producing cells are observed in the wild-type luteinized interstitial cells. However, few lipid droplets and well-developed smooth endoplasmic reticulum (ser) are recognized in the ArKO cells. Mitochondria in the ArKO luteinized interstitial cells show a structure atypical of the steroid-producing cells. Golgi apparatus (G) is also evident in the ArKO interstitial cells. The abnormal features in the ArKO luteinized interstitial cells were reversed by $E_{2}$ supplementation. Bar: $1 \mu \mathrm{m}$. 


\section{A}

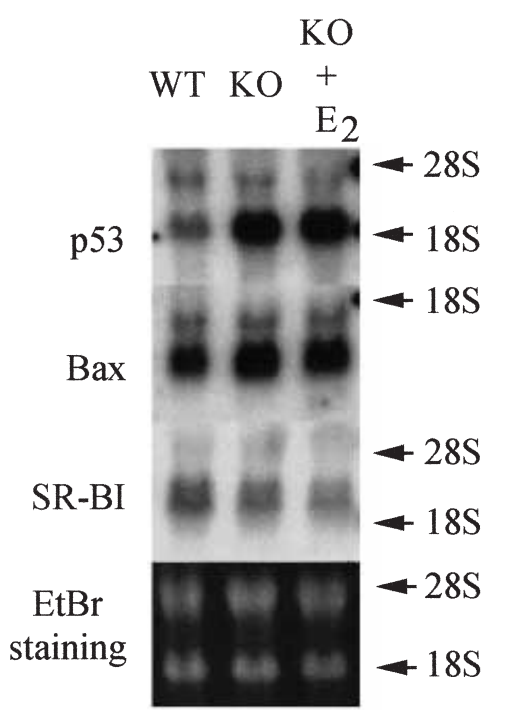

$\mathrm{B}$

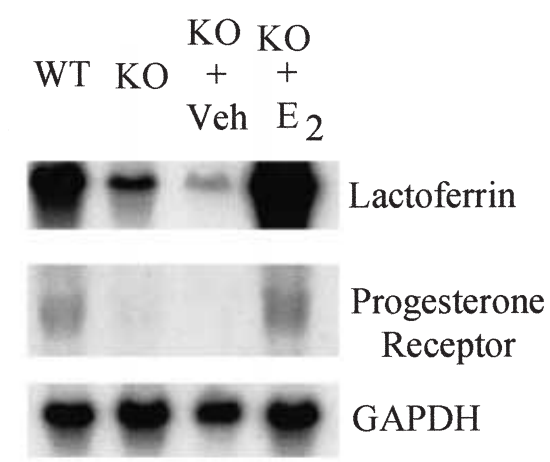

Figure 6 Alternations in gene expression in ArKO ovaries and uteri. (A) Expression of the p53, Bax and SR-BI genes was analysed by Northern blot hybridization using $20 \mu \mathrm{g}$ total RNAs from the ovaries of wild-type mice (WT), untreated ArKO mice (KO) and ArKO mice supplemented with $E_{2}\left(K O+E_{2}\right)$. The migration patterns of ribosomal RNA stained with ethidium bromide ( $\mathrm{EtBr}$ staining) are shown as a loading control. The experiment was repeated three times for the quantification of the signals. (B) Expression of the lactoferrin, progesterone receptor and GAPDH genes were analysed by Northern blot hybridization using $20 \mu \mathrm{g}$ total RNAs from the uteri from wild-type mice (WT), untreated ArKO mice $(\mathrm{KO})$, ArKO mice given vehicle alone $(\mathrm{KO}+\mathrm{Veh})$ or ArKO mice supplemented with $\mathrm{E}_{2}$ $\left(\mathrm{KO}+\mathrm{E}_{2}\right)$. The experiments were repeated twice for the quantification of the signals.

elevated level of expression of the pro-apoptotic genes in the ovaries of ArKO mice were ameliorated by the treatment. It is apparent that redundant endocrine/ paracrine/autocrine control mechanisms are involved in the regulation of ovarian functions in a combinatorial manner (Hsueh et al. 1994). Thus, experimental protocols which mimic the physiological hormonal milieu similar to those occurring in the wild-type female mice might be necessary to reverse the ovarian dysfunction of ArKO females.

As ArKO ovaries are defective in ovulation, all ovarian follicles of the mutant animals appear to undergo atretic degeneration. Apoptosis appears to be a process associated with follicular atresia (Hsueh et al. 1994, McGee \& Hsueh 2000). We observed apoptotic DNA fragmentation (data not shown) and expressions of pro-apoptotic genes such as p53 (Burns \& El-Deiry 1999, Tilly et al. 1995b) and Bax (Oltvai et al. 1993, Tilly et al. 1995a, Perez et al. 1999) with elevated levels in the ArKO ovaries compared with those seen in the wild-type ovaries. Thus, apoptotic cell death might be stimulated in the ArKO ovaries, this contributes to the occurrence of depletion of ovarian follicles at a relatively early stage of life in ArKO females when compared with the wild-type females.

$\alpha$ ERKO female mice showed failure of the normal maturational events leading to successful ovulation and luteinization (Couse \& Korach 1999). It was also reported that $\alpha E R K O$ females form large haemorrhagic cysts in the ovaries (Schomberg et al. 1999). Thus, these results, together with those of the present study, indicate that anovulation, defects in luteinization and haemorrhage formation might be due to defects in oestrogen actions mediated by ER $\alpha$.

\section{Acknowledgements}

We thank Dr Christina T Teng at National Institute of Environmental Heath Science, Research Triangle Park, NC, USA for a generous gift of a cDNA coding for murine lactoferrin. This work was supported, in part, by research grants provided by ONO Medical Research Foundation, TOYOTA High-Tech Research Grant Program (to K T), and the Ministry of Education, Science, Sports and Culture of Japan (to Y S). 


\section{References}

Billig H, Furuta I \& Hsueh AJW 1993 Estrogens inhibit and androgens enhance ovarian granulosa cell apoptosis. Endocrinology 133 2204-2212

Billig H, Furuta I \& Hsueh AJW 1994 Gonadotropin-releasing hormone directly induced apoptotic cell death in the rat ovary: biochemical and in situ detection of deoxyribonucleic acid fragmentation in granulosa cells. Endocrinology 134 245-252.

Braw RH \& Tsafriri A 1980 Effect of PMSG on follicular atresia in the immature rat. Journal of Reproduction and Fertility $\mathbf{5 9}$ 267-272.

Brodie AMH, Schwarzel WC, Shaikh AA \& Brodie HJ 1977 The effect of an aromatase inhibitor, 4-hydroxy-4-androstene-3,17dione, on estrogen dependent processes in reproduction and breast cancer. Endocrinology 100 1684-1695.

Britt KL, Drummond AE, Cox VA, Dyson M, Wreford NG, Jones MEE, Simpson ER \& Findlay JK 2000 An age-related ovarian phenotype in mice with targeted disruption of the Cyp19 (aromatase) gene. Endocrinology 141 2614-2623.

Burns TF \& El-Deiry WS 1999 The p53 pathway and apoptosis. Journal of Cell Physiology 181 231-239.

Couse JF \& Korach KS 1999 Estrogen receptor null mice: what have we learned and where will they lead us? Endocrine Reviews $\mathbf{2 0}$ 358-417.

Couse JF, Hewitt CS, Bunch DO, Sar M, Walker VR, Davis BJ \& Korach KS 1999 Postnatal sex reversal of the ovaries in mice lacking estrogen receptors $\alpha$ and $\beta$. Science 286 2328-2331.

Chun S-Y, Billig H, Tilly JL, Furuta I, Tsafriri A \& Hsueh AJW 1994 Gonadotropin suppression of apoptosis in cultured preovulatory follicles: mediatory role of endogenous insulin-like growth factor I. Endocrinology 135 1845-1853.

Chun S-Y, Eisenhauer KM, Minami S, Billig H, Perlas E \& Hsueh AWJ 1996 Hormonal regulation of apoptosis in early antral follicles: follicle-stimulating hormone as a major survival factor. Endocrinology 137 1447-1456.

Dupont S, Krust A, Gansmuller A, Dierich A, Chambon P \& Mark M 2000 Effect of single and compound knockouts of estrogen receptors $\alpha(E R \alpha)$ and $\beta(E R \beta)$ on mouse reproductive phenotypes. Development 127 4277-4291.

Eddy EM, Washburn TF, Bunch DO, Goulding EH, Gladen BC, Lubahn DB \& Korach KS 1996 Targeted disruption of the estrogen receptor gene in male mice causes alternation of spermatogenesis and infertility. Endocrinology 137 4796-4805.

Eisenhauer KM, Chun SY, Billig H \& Hsueh AJ 1995 Growth hormone suppression of apoptosis in preovulatory rat follicles and partial neutralization by insulin-like growth factor binding protein. Biology of Reproduction 53 13-20.

Fisher CR, Graves KH, Parlow AF \& Simpson ER 1998 Characterization of mice deficient in aromatase (ArKO) because of targeted disruption of the cyp19 gene. PNAS 95 6965-6970.

Graham-Lorence S, Khalil MW, Lorence MC, Mendelson CR \& Simpson ER 1991 Structure-function relationships of human aromatase cytochrome P-450 using molecular modeling and site directed mutagenesis. Journal of Biological Chemistry 266 11939-11946.

Hess RA, Bunick D, Lee K-H, Bahr J, Taylor JA, Korach KS \& Lubahn DB 1997 A role for oestrogens in the male reproductive system. Nature 390 509-512.

Hirshfield AN 1991 Development of follicles in the mammalian ovary. International Review of Cytology 124 43-101.

Hogan B, Beddington R, Costantini F \& Lacy E 1994 Manipulating the Mouse Embryo. A Laboratory Manual, edn 2. Cold Spring Harbor: Cold Spring Harbor Laboratory Press.

Honda S, Harada N, Ito S, Takagi Y \& Maeda S 1998 Disruption of sexual behavior in male aromatase-deficient mice lacking exons 1 and 2 of the cyp 19 gene. Biochemical and Biophysical Research Communications 252 445-449.
Hsueh AJW, Billig H \& Tsafriri A 1994 Ovarian follicle atresia: a hormonally controlled apoptotic process. Endocrine Reviews $\mathbf{1 5}$ 707-724.

Krege JH, Hodgin JB, Couse JF, Enmark E, Warner M, Mahler JF, Sar M, Korach KS, Gustafsson J-Å \& Smithies O 1998 Generation and reproductive phenotypes of mice lacking estrogen receptor $\beta$. PNAS 95 15677-15682.

Lephart ED \& Simpson ER 1991 Assay of aromatase activity. Methods in Enzymology 206 477-483.

Lubahn DB, Moyer JS, Golding TS, Couse JF, Korach KS \& Smithies O 1993 Alternation of reproductive function but not prenatal sexual development after insertional disruption of the mouse estrogen receptor gene. PNAS 90 11162-11166.

McGee EA \& Hsueh AJW 2000 Initial and cyclic recruitment of ovarian follicles. Endocrine Reviews 21 200-214.

Mirkes PE 1985 Simultaneous banding of rat embryo DNA, RNA, and protein in cesium trifluoroacetate gradients. Analytical Biochemistry 148 376-383.

Nemoto Y, Toda K, Ono M, F-Adachi K, Saibara T, Onishi S, Enzan H, Okada T \& Shizuta Y 2000 Altered expression of fatty acid-metabolizing enzymes in aromatase-deficient mice. Journal of Clinical Investigation 105 1819-1825.

Oltvai ZN, Milliman CL \& Korsmeyer SJ 1993 Bcl-2 heterodimerizes in vivo with a conserved homolog, Bax, that accelerates programmed cell death. Cell 74 609-619.

Perez GI, Robles R, Knudson CM, Flaws JA, Korsmeyer SJ \& Tilly JL 1999 Prolongation of ovarian lifespan into advanced chronological age by Bax-deficiency. Nature Genetics 21 200-203.

Richards JS 1994 Hormonal control of gene expression in the ovary. Endocrine Reviews 15 725-751.

Sambrook J, Fritsch EF \& Maniatis T (eds) 1989 Molecular Cloning: $A$ Laboratory Manual, edn 2. Cold Spring Harbor: Cold Spring Harbor Laboratory Press.

Schomberg DW, Couse JF, Mukherjee A, Lubahn DB, Sar M, Mayo KE \& Korach KS 1999 Targeted disruption of the estrogen receptor- $\alpha$ gene in female mice: characterization of ovarian responses and phenotype in the adult. Endocrinology 140 2733-2744.

Shoham Z \& Schachter M 1996 Estrogen biosynthesis - regulation, action, remote effects, and value of monitoring in ovarian stimulation cycles. Fertility and Sterility 65 687-701.

Tada A, Sasaki H, Nakamura J, Yoshihama M \& Terashima Y 1993 Aromatase activity and the effect of estradiol and testosterone on DNA synthesis in endometrial carcinoma cell lines. Journal of Steroid Biochemistry and Molecular Biology 44 661-666.

Takeda K, Tanaka T, Shi W, Matsumoto M, Minami M, Kashiwamura S, Nakanishi K, Yoshida N, Kishimoto T \& Akira S 1996 Essential role of Stat 6 in IL-4 signaling. Nature $\mathbf{3 8 0}$ 627-630.

Terashima M, Toda K, Kawamoto T, Kuribayashi I, Ogawa Y, Maeda T \& Shizuta Y 1991 Isolation of a full-length cDNA encoding mouse aromatase P450. Archives of Biochemistry and Biophysics 285 231-237.

Thomas KR \& Capecchi MR 1987 Site-directed mutagenesis by gene targeting in mouse embryo-derived stem cells. Cell $\mathbf{5 1}$ $503-512$.

Tilly JL, Billig H, Kowalski KI \& Hsueh AJW 1992 Epidermal growth factor and basic fibroblast growth factor suppress the spontaneous onset of apoptosis in cultured rat ovarian granulosa cells and follicles by a tyrosine kinase-dependent mechanism. Molecular Endocrinology 6 1942-1950.

Tilly JL, Tilly KI, Kenton ML \& Johnson AL 1995a Expression of members of the $\mathrm{Bcl}-2$ gene family in the immature rat ovary: equine chorionic gonadotropin-mediated inhibition of granulosa cell apoptosis is associated with decreased Bax and constitutive Bcl-2 and $\mathrm{Bcl}-\mathrm{x}_{\mathrm{long}}$ messenger ribonucleic acid levels. Endocrinology 136 232-241. 
Tilly KI, Banerjee S, Banerjee PP \& Tilly JL 1995 b Expression of the p53 and Wilms' tumor suppressor genes in the rat ovary: gonadotropin repression in vivo and immunohistochemical localization of nuclear p53 protein to apoptotic granulosa cells of atretic follicles. Endocrinology 136 1394-1402.

Weihua Z, Saji S, Mäkinen S, Cheng G, Jensen EV, Warner M \& Gustafsson J-Å 2000 Estrogen receptor (ER) $\beta$, a modulator of ER $\alpha$ in the uterus. PNAS 97 5936-5941.
Yamada K, Harada N, Tamaru M \& Takagi Y 1993 Effects of changes in gonadal hormones on the amount of aromatase messenger RNA in mouse brain diencephalon. Biochemical and Biophysical Research Communications 195 462-468.

Received 27 December 2000

Accepted 1 March 2001 